\title{
ВІДДАЛЕНІ РЕЗУЛЬТАТИ МУКОГІНГІВООСТЕОПЛАСТИКИ У ХВОРИХ ІЗ ТЯЖКИМИ ФОРМАМИ ГЕНЕРАЛІЗОВАНОГО ПАРОДОНТИТУ
}

\begin{abstract}
Резюме. Серед усіх стоматологічних захворювань хвороби пародонта займають одне із провідних місць, враховуючи поширеність цієї патології серед населення та її наслідки (втрата зубів і порушення фуункції зубощелепної системи). Тяжкість перебігу хвороби, часті рецидиви й ускладнення призводять до зниження якості життя пацієнтів, порушення фуннції жування та мовлення, значних соціально-економічних збитків. Це вимагає подальшої розробки нових схем лікування.

Мета дослідження - розробити нові підходи до лікування хворих із тяжкими формами генералізованого пародонтиту (ГП), випередити у післяопераційному періоді оголення шийок зубів та зниження висоти альвеолярного краю уосконаленням мукогінгівоостеопластики та корекції функції печінки шляхом призначення у перед- та післяопераційному періодах адекватного медикаментозного супроводу.

Матеріали і методи. Прооперовано 60 хворих із тяжкою формою хронічного генералізованого пародонтиту. Залежно від методу лікування, усіх пацієнтів поділили на дві групи: 30 хворим на генералізований пародонтит II-III ступенів розвитку із жировим гепатозом печінки (перша група) проводили модифріковану мукогінгівоостеопластику із застосуванням у перед- та післяопераційному періодах аргініну глутамату і в післяопераційному періоді розчину мірамістину та метилурацилової мазі 3 мірамістином. Хворим другої групи (30 осіб) без супутньої патології проводили мукогінгівоостеопластику. Оцінку результатів клінічного дослідження здійснювали за даними загальноклінічних, біохімічних методів.

Результати досліджень та їх обговорення. Через 3 місяці після операції суттєвої різниці між станом хворих першої і другої груп не було. Через 12 місяців - у 26 осіб першої групи в ділянці оперованих зубів утворилось стійке зубоясенне прикріплення за типом циркулярної зв'язки, при ренгенологічному контролі виявлено острівки осифрікації і стабілізації патологічного процесу, а у хворих другої групи в 4 випадках були наявні поодинокі кишені, явища гінгівіту. Показник PI у віддалений термін спостереження через 12 місяців поступово зменшувався. Порівняно з даними до операційного втручання, індекс PI відрізнявся у хворих другої групи в 1,18 раза, а першої групи - у 1,20 разів через 12 місяців відповідно. У пацієнтів другої групи, в яких крім пенетрацій, використовували місцеві медикаменти, які ми запропонували, зниження рівня С-РБ було більшим і склало 9,24 раза через 12 місяців. Ще кращі результати спостерігали у хворих першої групи, а через 12 місяців були несуттєвими. Висновки. Комплексне лікування із використанням аргініну глутамату у хворих першої групи, що сприяло найбільшому зниженню вмісту оксипроліну через 1; 6 і 12 місяців після терапії $(1,42$ і 1,38) раза, мало виражену дію на гальмування розпаду колагену в тканинах пародонта. Дослідження показало, що найбільший вплив на регуляцію активності ЛФ у сироватці крові хворих на ГП мав спосіб лікування, який застосовували у першій групі. Мукогінгівоостеопластика при лікуванні тяжких фрорм ГП в поєднанні з аргініном глутаматом знижували активність КФ у сироватці крові, особливо у хворих першої групи. Дані щодо змін активності трансаміназ у сироватці крові показали, що запропоноване медикаментозне лікування в поєднанні 3 хірургічною методикою мало суттєвий вплив на регуляцію активності трансаміназ у пацієнтів із тяжкими формами ГП.
\end{abstract}

Ключові слова: генералізований пародонтит; гепатоз печінки; мукогінгівоостеопластика.

вступ Серед усіх стоматологічних захворювань хвороби пародонта займають одне із провідних місць, враховуючи поширеність цієї патології серед населення та її наслідки (втрата зубів і порушення срункції зубощелепної системи). Тяжкість перебігу хвороби, часті рецидиви й ускладнення призводять до зниження якості життя пацієнтів, порушення фрункції жування та мовлення, значних соціально-економічних збитків. Це вимагає подальшої розробки нових схем лікування.

На сьогодні доведено, що етіологію та патогенез генералізованого пародонтиту (ГП) необхідно характеризувати як інтегральний процес, що відбувається унаслідок порушень фрункціонального стану як тканин пародонта при тяжких форм ГП, так і різноманітних органів та систем [4, 7]. На думку низки науковців, одним із провідних фракторів розвитку генералізованого пародонтиту вважають порушення фрункції печінки, оскільки ії фрункції супроводжуються значними порушеннями бар'єрної функції і резистентності організму, що спричиняє затяжний перебіг загострення, зниження ефективності загальноприйнятого лікування. Тяжкість перебігу ГП, за даними наукової літератури, залежить від функціонального стану печінки [6, 7].

Недивлячись на значну кількість наукових праць та практичних рекомендацій щодо лікування генералізованого пародонтиту, немає достатньо досліджень, присвячених хірургічному лікуванню тяжких форм генералізованого пародонтиту та питань взаємозв'язку кровопостачан- ня тканин присінка рота з щільністю кісткової структури щелепних кісток, вибору тактики хірургічної корекції присінка рота, а також морфологічних та ультраструктурних змін слизової оболонки присінка рота при використанні різних схем оптимізації остеогенезу і комплексного лікування хворих на генералізований пародонтит.

Метою дослідження було розробити нові підходи до лікування хворих із тяжкими фрормами ГП, випередити у післяопераційному періоді оголення шийок зубів та зниження висоти альвеолярного краю удосконаленням мукогінгівоостеопластики та корекції фрункції печінки шляхом призначення в перед- та післяопераційному періодах адекватного медикаментозного супроводу.

МАТЕРІАЛИ І МЕТОДИ Під час підготовки Хворих до операції на пародонті у 30 осіб при УЗ-обстеженні органів черевної порожнини діагностовано жировий гепатоз. Таких хворих направили до лікаря-гастроентеролога та провели поглиблену діагностику та подальше лікування згідно із затвердженими протоколами. Ґрунтуючись на результаті біохімічних досліджень із метою корекції антоксиданого захисту призначали аргінін глутамат.

Прооперовано 60 хворих із тяжкою фрормою хронічного генералізованого пародонтиту. Залежно від методу лікування, усіх пацієнтів поділили на дві групи:

30 хворим на генералізований пародонтит II-III ступенів розвитку із жировим гепатозом печінки (перша група) проводили модисріковану мукогінгівоостеопласти- 
ку із застосуванням у перед- та післяопераційному періодах аргініну глутамату і в післяопераційному періоді розчину мірамістину та метилурацилової мазі з мірамістином. Хворим другої групи (30 осіб) без супутньої патології проводили мукогінгівоостеопластику. Оцінку результатів клінічного дослідження здійснювали за даними загальноклінічних, біохімічних методів.

РЕЗУЛЬТАТИ ДОСЛІДЖЕНЬ ТА ЇХ ОБГОВОРЕННЯ Через 3 місяці після операції суттєвої різниці між станом хворих першої і другої груп не було. Через 12 місяців - у 26 пацієнтів першої групи у ділянці оперованих зубів утворилось стійке зубоясенне прикріплення за типом циркулярної зв'язки, при ренгенологічному контролі виявлено острівки осифрікації і стабілізації патологічного процесу, а у хворих другої групи в 4 випадках були наявні поодинокі кіскові кишені, явища гінгівіту.

Показник РІ у віддалений термін спостереження через 12 місяців поступово зменшувався. Порівняно з даними до операційного втручання, індекс РІ відрізнявся у хворих другої групи в 1,18 раза, а першої групи - в 1,20 разів через 12 місяців відповідно. У пацієнтів другої групи, в яких крім пенетрацій використовували місцеві медикаменти, які ми запропонували, зниження рівня С-РБ було більшим і склало 9,24 раза через 12 місяців. ще ліпші результати спостерігалися у хворих першої групи, через 12 місяців, проте були несуттєвими.

Показники церулоплазміну до лікування у першій

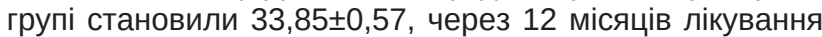
знизилися на $36,16 \%(24,86 \pm 0,55)$. У хворих другої групи активність церулоплазміну до лікування $-33,46 \pm 0,54$ зменшувалися на $26,45 \%(26,46 \pm 0,65)$. Проте в жодній групі не вдалося досягти даних як у здорових.

У другій групі оксипролін знижувався особливо виражено: із $(6,90 \pm 0,13)$ мкг/мл до $(4,99 \pm 0,18)$ мкг/мл через 12 місяців після терапії відповідно, тобто в 1,38 раза.

За вмістом оксипроліну в ротовій рідині хворих на ГП II-III ступенів у першій групі різниця 3 даними хворих другої групи після лікування склала 1,18; 1,12 і 1,10 раза через 1 місяць, півроку і рік відповідно. Хоча зниження рівня оксипроліну було значним в усіх групах, проте даних у здорових досягнуто не було.

Активність ЛФ у сироватці крові зростала на 36,67\% відразу після операції і, незначно коливаючись, практично утрималася в такому стані й через рік, а різниця 3 даними до операції склала 37,50 \%. Відмінність між першою і другою групами через 1 місяць, за даними активності ЛФ, була 4,33 \%, через 6 місяців - 8,17 \%, через 12 - 9,47 \% відповідно. При цьому в жодній групі не вдалося досягти даних як у здорових.

Активність КФ у сироватці крові хворих другої групи становили: із $(205,63 \pm 9,15)$ нмоль/с.л до лікування вона знизилась до $(156,83 \pm 9,16)$ нмоль/с.л через 12 місяців відповідно. Особливо помітним було зменшення активності КФ у хворих першої групи: на 44,13 \% через 12 місяців.

\section{СПИСОК ЛІТЕРАТУРИ}

1. Герасимова Л. П. Применение ангиопротектора Докси-Хем в комплексном лечении воспалительных заболеваний пародонта / Л. П. Герасимова // Медицинский вестник Башкортостана. -2006 . - № 1. - С. 229-231.

2. Грудянов А. И. Методы хирургического лечения пародон-
Проведнне лікування мало також позитивний вплив на активність трансаміназ у сироватці крові. Хоча показники активності АлАт і АсАт у сироватці крові в обстежених хворих на ГП II-III ступенів розвитку не виходили за межі референтних величин, все ж таки порівняння 3 групою здорових пацієнтів показало суттєве підвищення активності цих ферментів. При цьому комплексним лікуванням пацієнтів було досягнуто достовірного зниження активності АлАт, що до лікуваня становила $(27,27 \pm 1,77)$ од. л, через 12 місяців - $(17,16 \pm 0,68)$ од. л лише у першій групі, а в другій групі до лікування - $(29,71 \pm 2,34)$ од. л, через рік - $(20,91 \pm 1,69)$ од. л. Активність цієї трансамінази у сироватці крові найбільше наближалася до показників здорових у хворих першої групи, при цьому різниця 3 даними до лікування була суттєвою на всіх етапах обстеження.

Подібні закономірності були і стосовно активності АсАт, що становила у першій групі до лікуваня $(29,21 \pm 2,25)$ од. л, через12 місяців після лікування - $(21,30 \pm 1,57)$ од. л, а в другій групі - до лікування $(29,31 \pm 2,61)$ од. л, через рік - $(24,22 \pm 1,57)$ од. л у сироватці крові хворих на ГП II-III ступенів розвитку. Цей показник також не виходив за межі рефрерентних величин, але як і АлАт був близьким до верхньої межі норми.

ВИСновкИ 1. Комплексне лікування із використанням препарату аргініну глутамату в пацієнтів першої групи, що сприяло найбільшому зниженню вмісту оксипроліну через 1; 6 і 12 місяців після терапії (1,42 і 1,38 раза) мало виражену дію на гальмування розпаду колагену в тканинах пародонта.

2. Результати досліджень показали, що найбільший вплив на регуляцію активності ЛФ у сироватці крові хворих на ГП мав спосіб лікування, який застосовано у першій групі.

3. Мукогінгівоостеопластика при лікуванні тяжких фрорм ГП у поєднанні з аргініном глутаматом знижували активність КФ у сироватці крові, особливо в пацієнтів першої групи.

4. Дані щодо змін активності трансаміназ у сироватці крові показали, що запропоноване медикаментозне лікування в поєднанні з хірургічною методикою мало суттєвий вплив на регуляцію активності трансаміназ у хворих на тяжкі форми ГП із жировим гепатозом, і становило в першій групі до лікування - $(27,27 \pm 1,77)$ од. л, $(29,21 \pm$ $2,25)$ од. л через 12 місяців після лікування - $(17,16 \pm 0,68)$ од. л, $(21,30 \pm 1,57)$ од. л. Показники АлАТ, АсАТ в другій групі до лікування - $(29,71 \pm 2,34)$ од. л, $(29,31 \pm 2,61)$ через 12 місяців після лікування - $(20,91 \pm 1,69)$ од. л, $(24,22 \pm$ $1,57)$ од. л.

Перспективи подальших досліджень полягають у вивченні віддаленних результатів запропонованого методу вдосконалення технологічної ланки операції мукогігівоостеопластики з використанням лазера для лікування хворих із тяжкими формами генералізованого пародонтиту. 
вання захворювань пародонта / Л. 3. Деркач // Архів клінічної медицини. - 2009. - № 2 (15). - С. 20-22.

4. Кашівська Р. С. Стан тканин пародонта у хворих на генералізований пародонтит при захворюваннях гепатобіліарної системи та обгрунтування медикаментозної корекції виявлених порушень : автореср. дис. на здобуття наук. ступеня канд. мед. наук. - Івано-Франківськ, 2016. - 20 с.

5. Мазур І. П. Застосування остеотропних засобів в комплексі підтримуючої пародонтальної терапії у хворих на генералізований пародонтит (довготривалі спостереження) / І. П. Мазур // Вісник стоматології. - 2005. - № 4. - С. 32-35.

6. Мельничук Г. М. Гінгівіт, пародонтит, пародонтоз: особливості лікування : навч. посіб. - вид. 5-те, випр. і доп. / Г.М.Мельничук, М. М. Рожко, Л. В. Завербна. - Івано-Франківськ, 2011. -328 c.
7. Назарян Р. С. Взаємний зв'язок морфоорункціональних змін у пародонті щурів з процесами вільнорадикального окиснення під впливом аліментарного фрактора / Р. С. Назарян // Вісник морфології. - 2003. - № 2. - С. 204-205.

8. Опыт использования остеопластического материала Остеопласт-К при хирургических вмешательствах на пародонте / Л. А. Дмитриева [и др.] // Стоматология. - 2007. - № 6. C. 53-55.

9. Остеокондуктивный материал EASY GRAFT в современной хирургической стоматологии / А. В. Павленко [и др.] // Дентальные технологии. - 2010. - № 1. - С. 26-31.

10. Павленко О. В. Особливості процесів репаратавної регенерації в коміркових відростках нижньої щелепи при пластиці десректів різними матеріалами / О. В. Павленко // Український морфологічний альманах. - 2009. - № 3. - С. 93-97.

Отримано 17.01.18

\section{CS. A. Ogienko}

Ivano-Frankivsk National Medical University

\section{REMOTE RESULTS OF MUCO-GINGIVAL OSTEOPLASTY IN PATIENTS WITH SEVERE FORMS OF GENERALIZED PERIODONTITIS}

Summary. Among all dental diseases, periodontal disease is one of the leading places, taking into account the prevalence of this pathology among the population and its consequences (loss of teeth and dysfunction of the tooth-jaw system). The severity of the disease, frequent relapses and complications lead to a decrease in the quality of life of patients, impaired chewing and speech, significant socio-economic losses. This requires further development of new treatment regimens.

The aim of the study - to develop new approaches to the treatment of patients with severe forms of generalized periodontitis, to prevent in the postoperative period the exposure of the neck teeth and to reduce the height of the alveolar margin, to improve mucogingival osteoplasty and to correct liver function by assigning adequate medical support in the pre and postoperative period.

Materials and Methods. 60 patients with severe forms of chronic generalized periodontitis were operated, depending on the method of treatment, all patients were divided into two groups: 30 patients with generalized periodontitis II-III degree of development with fatty liver hepatosis (group 1) were performed modified muco-gingival osteoplasty with application in the pre and postoperative period of preparation of arginine glutamate and in the postoperative period of the solution of miramistin and methyl uracil ointment with miramistinum. Patients of the group 2 (30 people) without concomitant pathology underwent muco-gingival osteoplasty. The evaluation of the results of the clinical study was carried out according to general-clinical, biochemical, patient surveys.

Results and Discussion. 3 months after the operation there was no significant difference between the patients' state of the groups 1 and 2. 12 months later -26 patients of group 1 in the area of operated teeth formed a stable tooth-aspartic attachment in the type of circular ligament, with radiological control, islets of oscillation and stabilization of the pathological process were found, and in patients of 2 groups in 4 cases, there were single skinned pockets, the phenomenon of gingivitis. Indicator of RI in remote monitoring period after 12 months gradually decreased. Comparing with the data before surgery, the RI index differed in patients in the group 2 in 1.18 times, and in the group 1 - in 1.20 times in 12 months, respectively. In patients of the group 2, in which, in addition to penetration, we used the local medicines we proposed, the decrease in C-RB was higher and was 9.24 times in 12 months. Even better results were observed in patients in the group 1, and after 12 months, however, it was negligible.

Conclusions. Complex treatment with the preparation of arginine glutamate in patients of the group 1, which contributed to the greatest reduction in the content of oxyproline after 1.6 and 12 months after therapy, 1.42 and 1.38 times, and had little effect on the inhibition of collagen collapse in the tissues of periodontal disease. Our study showed that the greatest influence on the regulation of LF activity in blood serum of patients with HF had a treatment method applied in the group 1. Muco-gingival osteoplasty in the treatment of severe forms of GP in combination with arginine glutamate reduced the activity of CF in serum, especially in patients in the group 1. Data on changes in the activity of transaminases in serum showed that the proposed drug treatment, in combination with the surgical technique, had a significant effect on the regulation of the activity of transaminases in patients with severe forms of GP.

Key words: generalized periodontitis; liver hepatosis; muco-gingival osteoplasty.

(с). А. Огиенко

ГВУз “Ивано-Франковский национальный медицинский университет”

\section{ОТДАЛЕННЫЕ РЕЗУЛЬТАТЫ МУКОГИНГИВООСТЕОПЛАСТИКИ В БОЛЬНЫХ С ТЯЖЕЛОЙ ФОРМОЙ} ГЕНЕРАЛИЗОВАННОГО ПАРОДОНТИТА

Резюме. Среди всех стоматологических заболеваний болезни пародонта занимают одно из ведущих мест, учитывая распространенность этой патологии среди населения и его последствия (потеря зубов и нарушение функции зубочелюстной системы). Тяжесть течения болезни, частые рецидивы и осложнения приводят к снижению качества жизни пациентов, нарушение фрункции жевания и речи, значительных социально-экономических убытков. Это требует дальнейшей разработки новых схем лечения. Цель исследования - разработать новые подходы к лечению больных с тяжелыми срормами генерализованного пародонтита (ГП), предупредить в послеоперационном периоде обнажение шеек зубов и снижение высоты альвеолярного края со- 
вершенствованием мукогингивоостеопластики и коррекции фрункции печени путем назначения в перед- и послеоперационном периодах адекватного медикаментозного сопровождения.

Материалы и методы. Были прооперированы 60 больных с тяжелой формой хронического генерализованного пародонтита. В зависимости от метода лечения, всех пациентов разделили на две группы: 30 больным генерализованным пародонтитом II-III степеней развития с жировым гепатозом печени (первая группа) проводили модисицированную мукогингивоостеопластику с применением в перед- и послеоперационном периодах препарата аргинина глутамата и в послеоперационном периоде раствора мирамистина и метилурациловои мази с мирамистином. Больным второй группы (30 лиц) без сопутствующей патологии проводили мукогингивоостеопластику. Оценку результатов клинического исследования осуществляли по данным общеклинических, биохимических, методов.

Результаты исследований и их обсуждение. Через 3 месяца после операции существенной разницы между состоянием больных первой и второй групп не было. Через 12 месяцев - у 26 лиц первой группы в области оперированных зубов образовалось устойчивое зубодесневого прикрепления по типу циркулярной связи, при рентгенологические контроле обнаружено островки оссисикации и стабилизации патологического процесса, а у больных второй группы в 4 случаях имелись единичные карманы, явления гингивита. Показатель РИ в отдаленные сроки наблюдения через 12 месяцев постепенно уменьшался. По сравнению с данными до операционного вмешательства, индекс РИ отличался у больных второй группы в 1,18 раза, а первой группы - в 1,20 раза через 12 месяцев соответственно. У больных второй группы, в которых кроме пенетраций, использовали предложенные нами местные медикаменты, снижение уровня С-РБ было большим и составило 9,24 раза через 12 месяцев. Еще лучшие результаты наблюдались у больных первой группы, а через 12 месяцев, однако, были несущественными. Выводы. Комплексное лечение с использованием препарата аргинина глутамата у больных первой группы, которое способствовало наибольшему снижению содержания оксипролина через 1; 6 и 12 месяцев после терапии (1,42 и 1,38 раза), имело выраженное действие на торможение распада коллагена в тканях пародонта. Исследование показало, что наибольшее влияние на регуляцию активности ЩФ в сыворотке крови больных ГП имел способ лечения, применяемый в первой группе. Мукогингивоостеопластика при лечении тяжелых форм ГП в сочетании с аргинином глутаматом снижали активность КФ в сыворотке крови, особенно у больных первой группы. Данные об изменениях активности трансаминаз в сыворотке крови показали, что предложенное медикаментозное лечение в сочетании с хирургической методикой, имело существенное влияние на регуляцию активности трансаминаз у пациентов с тяжелыми формами ГП.

Ключевые слова: генерализованный пародонтит; гепатоз печени; мукогингивоостеопластика. 